\title{
THE ROLE OF TERMINAL 3 ULTIMATE SOEKARNO HATTA INTERNATIONAL AIRPORT IN SUPPORTING INDONESIA TOURISM DEVELOPMENT
}

\author{
Anita Mega Mahardani' ${ }^{1}$, Yasmin Nurjanah ${ }^{2}$ \\ 1. STMT Trisakti, 2. STMT Trisakti \\ corresponding author: Anitamahardani9@gmail.com
}

\begin{abstract}
Technology has evolved, especially in the field of air transportation. The dynamic of air transportation technology have seen through the competitions between airports all around the world, when the airports strive to serve as many passengers as possible and provide modern infrastructure along with the latest technology. The development of airport infrastructure positively affects the tourism of a country. If the tourism of a country continuously growing, consequently the country's economy will be flourished. The biggest hub airport in Indonesia, Soekarno-Hatta International Airport, plays an important role in providing the best facilities for the tourists. The latest innovation from the airport, Terminal 3 Ultimate, has been capable to advertise the tourism destinations and to attract tourists to visit unique destinations in Indonesia.
\end{abstract}

Keyword: role of the airport, tourism development, tourism promotion, airport capacity and service, tourism information

\section{Introduction}

Tourism and transportation closely related to each other. The improvement of transportation facilities especially on the air transportation encourages the advancement of tourism. A massive tourism development could not be done without the contribution of every single component in transportation systems. On the contrary, expansion occurred in tourism industry can create a demand that meets the needs of tourists for transportation. For tourism industry, transportation is the key factor that enables tourists to travel from their residences to their destination (Prideaux, 2000).

Accessibility is the main function behind the basics of tourism transport. (Ricardianto, Djajaputra, \& Martono, 2017). In order to reach the destination, tourists will use any transportation mode. Therefore, tourism could not developed without the availability of transportation facility and infrastructure, especially for air transportation. Currently air transport is the 
best way to travel safely and comfortably. Using air transportation, tourist can decrease their time to travel and make they can spend more time in their destination. Air transportation plays a major role in developing tourism and economy of many developing countries in which it contributes to the economic growth (Basnet, 2015). As airport infrastructure is one of important elements in tourism activities, the airport must be able to provide complete and convenient facilities. Because the experience of the tourist at the airport could be defines their beginning experience of doing tourism activities (Khadaroo \& Seetanah, 2008).

The previous research stated that air transportation is one of transportation mode that growing tremendously in Indonesia (Marty, 2016). This statement propped by the supports given from the Indonesian government in transportation sector through various tourism infrastructures development such as terminals, toll roads (highways), and especially airports (Simarmata \& Keke, 2017). It is proved with the establishment of the new terminal, which is terminal 3 ultimate in Soekarno Hatta International Airport that operated by PT. Angksa Pura II. As the Indonesia main gateway, Soekarno Hatta International Airport have an important key role to support Indonesia tourism development. Terminal 3 ultimate begun operated on August 9, 2016, with the total area 422,804 square meters, it can accommodate up to 62 million passengers per year, and is equipped with the most modern facilities and information technology system. Terminal 3 is undeniable as one of the success factors of SoekarnoHatta International Airport won the award of Skytrax as the World's Most Improved Airport in March 2017 for being the fastest growing airport around the world. As an airport operator, PT. Angkasa Pura II facilitates the airport by providing a Tourist Information Center (TIC) in digital approach where tourists may get information on tourist attractions, transportation, accommodation and other travel related information in Indonesia not only through brochures and booklet, but also through digital visual. TIC provides domestic arrival area, a place in commercial zone that covers an area of 71,225 square meters. The area is divided into several zones, for food \& 
beverages in an area of 23,301 square meters, retailer 22,023 square meters, service 2,007 square meters, duty free shops 4,784 square meters, lounge 8,496 square meters, exhibition 1,493 square meters, and airlines' offices 19,121 square meters. The tourism campaign facilitation not only the availability of TIC but also billboard and video showing that shown the Indonesia tourism destination. Some traditional ornaments also available there. By the advanced facility, Terminal 3 expected to gain more passengers.

As the largest archipelago in the world that have more than 17.000 island with the land area around 1.91 million $\mathrm{km} 2$ and the oceans area is 6.279 million $\mathrm{km} 2$. Indonesia have a hundred of tourism destination in almost each island. The Indonesia government has announced 10 new destination brands to support the Wonderful Indonesia campaign. The program attempts to attract 15 million foreign tourists in 2017 and 20 million in 2018. The 10 destinations are Bandung, Bali, Jakarta, Riau Islands, Joglosemar (Yogyakarta, Surakarta and Semarang), the Coral Wonders (Wakatobi, Bunaken and Raja Ampat), Medan, Makassar, Lombok and Banyuwangi. In 2017, the number of passenger movement at Soekarno Hatta International Airport reached 60 million people. According to Statistic Center Indonesia, in 2016 the total of foreign tourists visiting Indonesia increased from $15.5 \%$ to 12.02 million people compared to 2015 , which was 9.73 million. Air transport services collaborate with all parties to meet the aims for support the growth of the economic, trade and tourism sectors (Martono \& Marina, n.d.).

Terminal 3 have a big potential to support the Indonesia tourism development because as we know Soekarno Hatta International Airport is the main gateway of Indonesia, and terminal 3 is the larger terminal compared with the two other terminal. Even though now only airlines from Skyteam alliance that already moved to terminal 3 ultimate, but later the other international airlines will also move from terminal 2 to terminal 3 ultimate. However, terminal 3 ultimate still face some problems such as the minimum accessibility inside and outside the airport, minimum utilization area used, and the important one is the minimum facility that provided to support the tourism campaign in the airport. So we made this research to analyze the significant role that can be done by terminal 3 ultimate Soekarno Hatta International Airport in supporting Indonesia tourism development through advertising Indonesia tourism object. We limit our research to Terminal 3 
Ultimate Soekarno Hatta International Airport, which is the providing facility in the airport towards tourism development in 2016-2017.

\section{Method}

This research conducted by using quantitative research method. One of the authors has been stated that quantitative research method concerned with collecting and analyzing data structured and can be represented numerically (Methods \& Week, 2012). From all theories the writers obtained, they mention that airport is a crucial part of a country. It has become a representative of a country for both domestic and international travelers. Airport also helps developing a country's tourism by providing connection to several tourist destinations.

For this research, the writers designed the experiment by using oneshot case study, since there are some other variables aside Terminal 3 Ultimate Soekarno Hatta International Airport that may influence the Indonesia Tourism. One-shot case study is an experiment, which is conducted without a comparison group and neither with a preliminary test. The data taken from primary source and secondary source. The primary data was from questionnaires distributed to passengers traveling from and to Terminal 3 Ultimate Soekarno Hatta International Airport, and from interview sources at terminal 3. Meanwhile, the secondary data taken through the previous researches, journals, and airport publications.

The population of this research is all passengers that are arriving, departing, and transit at the gates of Terminal 3 Soekarno-Hatta International Airport. The samples taken by using random sampling method. 25 samples were taken for the test, the questionnaires use 5 scores of Likert Scale. For analyzing the data, writers used simple linear regression analysis with Correlation Pearson Product Moment to analyze the correlation between Terminal 3 Ultimate Soekarno-Hatta International Airport as variable $\mathrm{X}$ (independent variable) and Indonesia tourism as variable $\mathrm{Y}$ (dependent variable). For the implementation of this analysis, we tried in two methods, which are with manual calculation and with SPSS 24. Simple 
linear regression and Correlation Pearson Product Moment used for Simple linear regression analysis is a statistical method that can summarize quantitatively within two continuous variables. Simple regression analysis purposes is to evaluate the relative impact of a predictor variable on a particular outcome (Zou, Tuncali, \& Silverman, 2003). There are one variable $\mathrm{X}$, and variable $\mathrm{Y}$, which gave value of $\mathrm{X}$, and it can be estimated by the average value of Y. (Altman \& Krzywinski, 2015). To test the hypothesis, writers conducted two-tail test with the help of SPSS. In this test, if $\alpha$ (significance) is less than or equal to 0.05 , it means that there are enough evidences to reject $\mathrm{H}_{\mathrm{o}}$ which means there is an important relationship between $\mathrm{X}$ and $\mathrm{Y}$. However, if $\alpha$ is bigger than 0.05 , it means that there is not enough evidence to reject $\mathrm{H}_{\mathrm{o}}$, which means there is no significance in a relationship between $\mathrm{X}$ and $\mathrm{Y}$.

After determining the importance of Terminal 3 Ultimate SoekarnoHatta International Airport towards Indonesian tourism development, the effectiveness of Indonesian tourism campaign in Terminal 3 Ultimate Soekarno-Hatta needed to analyze by looking through the growth of passenger movement in Terminal 3 Ultimate Soekarno-Hatta International Airport. The elements that evaluated for tourism campaign are Tourist Information Center (TIC)'s facilities, how Indonesian tourism branded under TIC control, how TIC's service in Terminal 3 Ultimate SHIA, how TIC promote Indonesian tourism, and how TIC deliver the tourism information product towards the passengers.

\section{Discussion and Result}

In order to examine the influence of independent variables on dependent variable, this research used simple linear regression analysis. The equation is as follow: $\mathrm{Y}=\mathrm{a}+\mathrm{b}$. $\mathrm{X}$. In this equation, $\mathrm{Y}$ is the dependent variable, $a$ act as the determinant coefficient, $b$ is the regression coefficient and $\mathrm{n}$ act as the number of samples. First, we need to determine the regression coefficient and the determinant coefficient by using these 
formulas. After the coefficient found, the formula is as follow: $\mathrm{Y}=-1.37+$ $0.21 \mathrm{x}$. This study used SPSS to determine the coefficients below .

Table 1.

\begin{tabular}{|c|c|c|c|c|c|c|}
\hline \multicolumn{7}{|c|}{ Coefficients $^{\mathrm{a}}$} \\
\hline \multicolumn{2}{|c|}{ Model } & \multicolumn{2}{|c|}{$\begin{array}{c}\text { Unstandardized } \\
\text { Coefficients }\end{array}$} & $\begin{array}{c}\text { Standardized } \\
\text { Coefficients }\end{array}$ & $\mathrm{t}$ & Sig. \\
\cline { 3 - 7 } & B & $\begin{array}{c}\text { Std. } \\
\text { Error }\end{array}$ & Beta & & \\
\hline 1 & (Constant) & - & .705 & & - & .078 \\
& & 1.302 & & & 1.846 & \\
\cline { 3 - 7 } & T3SHIA_role & .207 & .033 & .792 & 6.223 & .000 \\
\hline
\end{tabular}

Based on the table 1 by looking at the value in the unstandardized coefficients column, Indonesian tourism is a constant model, and the determinant coefficient is in the B column -1.302. As for the regression coefficient found in the B column in T3SHIA_role row is 0.207 . Therefore, the equation is as follow:

$$
\mathrm{Y}=-1.302+0.207 \mathrm{X}
$$

The equations, the results concluded as follow:

1) The constant value for T3 SHIA roles are -1.302 , which means that if T3 SHIA roles' score is 0 (zero), it means that the Indonesian tourism scores is -1.302 .

2) The regression coefficient equals to 0.207 determines that every 1 score deducted from T3 SHIA role, the value of Indonesian tourism increased by 0.207 with 95 percent at confidence level.

In order to determine the correlation between Terminal 3 Ultimate SHIA (X) and Indonesian Tourism (Y) evaluation conducted using Correlation Pearson Product Moment by calculating the r. The results obtained from manual calculation shows the value of $r$ is equal to 0.792 .

To test the validity by using SPSS, the value of $\mathrm{R}$ canbe seen in Table 1 in the standardized coefficients column, which shows the number 0.792 . This result indicates that the correlation of Terminal 3 Ultimate Soekarno- 
Hatta International Airport and Indonesian Tourism Development are strongly correlating with each other and the relationship between them are going towards the same direction. For determining, the percentage of independent variable's influence towards the dependent variable comes from the square of $\mathrm{R}$ from the table above.

Determinant coefficient $=\mathrm{R}$ square $\times 100 \%=0.627 \times 100 \%=62.7 \%$, meanwhile the other variable that influencing $\mathrm{Y}=100 \%-62.7 \%=37.3 \%$ this results means that the influence of Terminal 3 Ultimate Soekarno-Hatta International Airport towards Indonesian Tourism Development are significant compared to other aspects.

For testing the hypothesis, T-Test used with the confidence level of 95\% and error level $(\alpha) 5 \%$ to determine the significance of Terminal 3 Ultimate SHIA towards Indonesian tourism. The influence observed through significance score in which if the score is above 5\% means that Ho is accepted. There was no significance between $\mathrm{X}$ and $\mathrm{Y}$, as for the significance score is below 5\%, means that Ho was rejected and there was significance between $\mathrm{X}$ and $\mathrm{Y}$.

Determining Hypothesis

Ho: $\rho=0$ (there is no significant influence between Terminal 3 Ultimate SHIA towards Indonesian Tourism)

Ha: $\rho \neq 0$ (There is significant influence between Terminal 3 Ultimate SHIA towards Indonesian Tourism)

The significance level using standard measurement $\mathrm{a}=5 \%$. From the Table 1, the significant value of Terminal 3 SHIA towards Indonesian tourism is 0.000 . With $0.000>0.05$, Ha was rejected and Ho was accepted. It indicated that there was no significant influence between dependent variable and independent variable.

$\mathrm{T}$ distribution table in $\alpha=5 \%$ (two-tail test) with degree of freedom (df) determined the formula $\mathrm{n}-\mathrm{k}$ in which $\mathrm{n}$ is equal to the amount of observation, 25 . K equals to the amount of variables, 2 . 
The amount of $\mathrm{df}$ is 23 . By two-tail test, the result obtained from t table was 2.069. The requirements for t-test are as follow:

- $\quad \mathrm{t}$ table $<\mathrm{t}$ count $<\mathrm{t}$ table means that Ho was accepted and Ha was rejected

- $\quad \mathrm{t}$ count $<-\mathrm{t}$ table or $\mathrm{t}$ count $>\mathrm{t}$ table means Ho was rejected and $\mathrm{Ha}$ was accepted.

Based from the table 1 in t column, athe t count obtained was 6.223 and $t$ table for $\alpha=5 \%$ and $\mathrm{df}=23$, the $\mathrm{t}$ count was 2.069 , so the results is:

$-\mathrm{t}$ count $<-\mathrm{t}$ table $-6.223<-2.069$

The results concluded that the observation rejected Ho and accepted Ha, which means there was significant correlation between Terminal 3 Ultimate SHIA role with Indonesian tourism development and the results from the $\mathrm{t}$ test contradicts the previous analysis by using simple linear regression and correlation Pearson Product Moment.

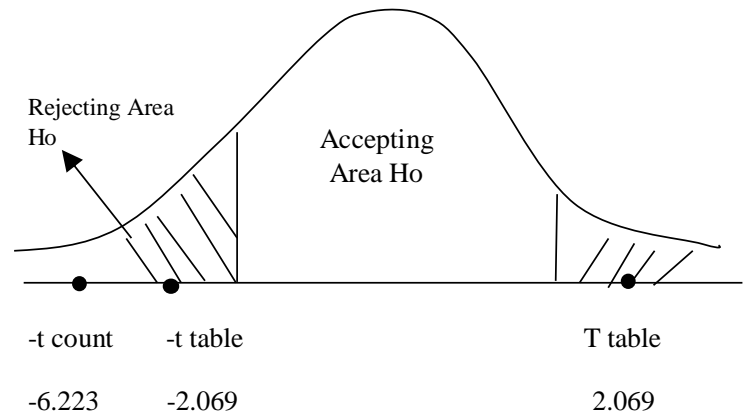

Figure 1.

After we found the significance of Terminal 3 Ultimate SoekarnoHatta International Airport towards Indonesian Tourism Development, we also need to compare the Terminal 3 Ultimate Soekarno-Hatta International Airport's passenger traffic with other terminal in Soekarno-Hatta International Airport. This comparison determines how effective Terminal 3 Ultimate Soekarno-Hatta International Airport in promoting Indonesian tourism. The comparison in this article only compares the performance of Terminal 3 Ultimate Soekarno-Hatta passenger movement with Terminal 1 and 2 in 2016 and 2017. Based from the statistics that writers obtained through PT. Angkasa Pura II as the state-own enterprise that operates 
Soekarno-Hatta International Airport, the passenger traffic in SoekarnoHatta International Airport 2016 cater 58.195.484 passenger movement, as from January until September 2017 the total of passengers moving inside Soekarno-Hatta International Airport around 46.409.795 people. Meanwhile in January until September 201643.243 .357 passengers moving inside Soekarno-Hatta International Airport. This shows that there is an increasing amount of passenger movement in Soekarno-Hatta International Airport. The increasing number of passenger movement is also contributed by Terminal 3 Soekarno-Hatta International Airport establishment.

Diagram 1.

Passenger traffic in Soekarno-Hatta International Airport 2016-2017

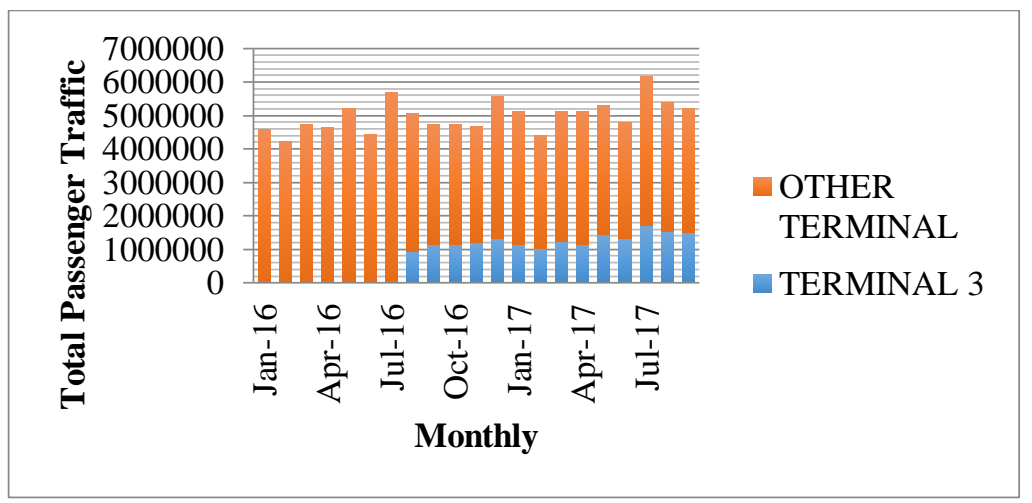

Source: PT. Angkasa Pura II

Figure 2.

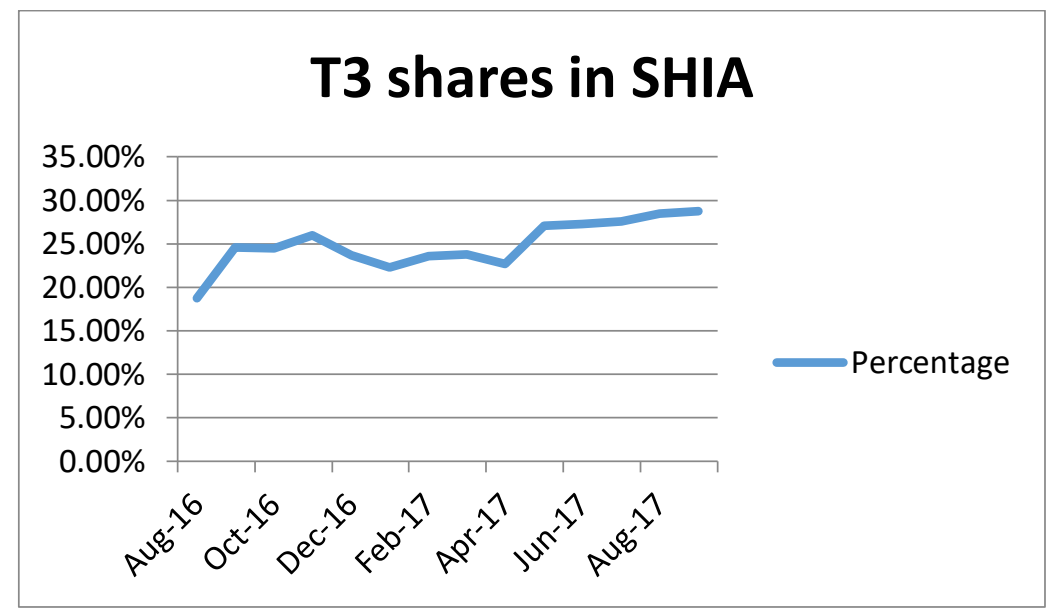

From the two diagrams above, it is concluded that Terminal 3 Ultimate Soekarno-Hatta International Airport has the potential in catering 
passenger traffics, but still left behind compared to its predecessor Terminal 1 and Terminal 2 since Terminal 3 Ultimate just established its services for a year. The number of passenger movement are proportionally increasing with the air traveler growth and the numbers of airlines operating in Terminal 3 Ultimate Soekarno-Hatta International Airport.

\section{Conclusion}

From the result of the study, the study concluded that airport has a strong and significant effect towards Indonesia tourism development. The number of calculation using simple linear regression method proves these and correlation Pearson product moment's result was 0.792, which means that there is a strong correlation. Based on the tables above, Terminal 3 Ultimate SHIA has enough covering passengers' destination choices. Terminal 3 covers $28.74 \%$ of passenger traffic in Soekarno-Hatta International Airport and the number will increase in the future regarding the development facility of terminal 3 ultimate. The results from single linear regression and Correlation Pearson Product Moment above indicate that Terminal 3 Ultimate Soekarno-Hatta International Airport was heading toward the same direction as to support Indonesian Tourism Development for now and later in the future. In order to achieve maximum result, Terminal 3 Ultimate SHIA should taking more attention in providing tourism campaign such as facilities, branding, promotion, service, and tourism information product.

Recommendation

* Terminal 3 should optimize the commercial area better.

* Terminal 3 have to increase their facility and service

* Intense cooperation are needed between ministry of tourism and the airport regulator (AP II)

* Terminal 3 shall expand Tourist Information Center

* Tourism Promotion in airport needed to be done frequently

* Terminal 3 must have certain uniqueness that can be memorable for the passengers 
* Terminal 3 shall coordinate with the airline to provide city tour

* Terminal 3 shall provide several types of entertainments for passengers

* Terminal 3 shall provide interactive website that could contain all of necessary info

* Terminal 3 shall coordinate with travel agent in order to sell travel package both online and offline

\section{References}

Altman, N., \& Krzywinski, M. (2015). Points of Significance: Simple linear regression. Nature Methods, 12(11), 999-1000. https://doi.org/10.1038/nmeth.3627

Basnet, S. (2015). AIR TRANSPORTATION AND ITS IMPACT UPON THE Case Study: Tribhuvan International Airport Degree Programme in Tourism, (November).

Khadaroo, J., \& Seetanah, B. (2008). The role of transport infrastructure in international tourism development: A gravity model approach. Tourism Management, 29(5),

831-840. https://doi.org/10.1016/j.tourman.2007.09.005

Martono, K., \& Marina, S. (n.d.). Domestic Air Transport Regulations in Indonesia, 3(1), 1-19.

Marty, Y. (2016). Airline Customer Retention in Indonesia 2015. International Journal of Management Sciences and Business Research, 2015(2), 41-53.

Methods, F., \& Week, I. (2012). Introduction to Quantitative Research Introduction to quantitative research, 4(c), 12-18.

Prideaux, B. (2000). The role of the transport system in destination development. Tourism Management, 21(1), 53-63. https://doi.org/10.1016/S0261-5177(99)00079-5

Ricardianto, I. P., Djajaputra, D. G., \& Martono, P. D. (2017). Air Transport and Tourism in Indonesia. IOSR Journal of Applied Chemistry, 10(5), 01-19. https://doi.org/10.9790/5736-1005010119

Simarmata, J., \& Keke, Y. (2017). The Influence of Travel Agent , Infrastructure and Accommodation on Tourist Satisfaction, 28(Ictgtd 2016), 281-283.

Zou, K. H., Tuncali, K., \& Silverman, S. G. (2003). Correlation and Simple Linear Regression. Radiology, 227(3), 617-628. https://doi.org/10.1148/radiol.2273011499

https://www.bps.go.id/Brs/view/id/1323

http://www.indonesia-tourism.com/

http://kemenpar.go.id/asp/ringkasan.asp?crhal=2\&c=110\&ref

https://bps.go.id/linkTableDinamis/view/id/807 
https://www.bps.go.id/website/pdf_publikasi/Indikator-Ekonomi-Desember2016.pdf

https://id.wikipedia.org/wiki/Terminal_3_Bandar_Udara_Internasional_Soe karno-Hatta

http://industri.bisnis.com/read/20170218/12/629896/kunjungan-wisman2016-lebihi-target-12-juta-orang

http://www.angkasapura2.co.id/en/informasi/siaran-pers-detail/soekarnohatta-international-airport-achieved-the-skytrax-worlds-mostimproved-airport-1241

http://www.iata.org/pressroom/pr/Pages/2015-03-12-01.aspx 